\title{
AGENDA POWER IN BRAZIL'S CÂMARA DOS DEPUTADOS, 1989-98
}

\author{
BY OCTAVIO AMORIM NETO, GARY W. COX, \\ and MATHEW D. MCCUBBINS*
}

\section{INTRODUCTION}

\begin{abstract}
A recent wave of research has been investigating the structure of veto and proposal power within democratic assemblies, in order to derive testable implications about the legislative process. ${ }^{1}$ In this article we explore the proposition that all majority governments in systems allowing joint tenure of legislative and executive posts constitute what we call parliamentary agenda cartels. An agenda cartel—at least in its ideal type - is any mechanism for ensuring that the legislative agenda is first hammered out within the cartel and then imposed on the assembly. A parliamentary agenda cartel is one in which the "hammering out" stage is such that each component party of the cartel has a veto on the place-
\end{abstract}

\footnotetext{
* Earlier versions of this paper were presented at the annual meeting of the American Political Science Association, Washington, D.C., August 2000, at the Centre for Brazilian Studies at Oxford University in October 2000, and at the Getulio Vargas Foundation in Rio de Janeiro in August 2002.

The authors thank Brian Crisp, Argelina C. Figueiredo, Fernando Limongi, Carlos Pereira, David Samuels, and Fabiano Santos for their comments; Juliana Estrella, Luiz Lourenço, Rodrigo R. A. Pinto, and César Zucco Jr. for their research assistance; and Argelina C. Figueiredo and Fernando Limongi for kindly sharing their Brazilian roll-call and legislative input data. Professors Cox and McCubbins acknowledge the support of the NSF grant SES-9905224.

${ }^{1}$ See, for example, Hebert Döring, "Time as a Scarce Resource: Government Control of the Agenda," in Herbert Döring, ed., Parliaments and Majority Rule in Western Europe (New York: St. Martin's Press, 1995); idem, "Parliamentary Agenda Control and Legislative Outcomes in Western Europe,” Legislative Studies Quarterly 26 (February 2001); John D. Huber, Rationalizing Parliament: Legislative Institutions and Party Politics in France (Cambridge: Cambridge University Press, 1996); Keith Krehbiel, Pivotal Politics: A Theory of U.S. Lawmaking (Chicago: University of Chicago Press, 1998); Gary W. Cox, Mikitaka Masuyama, and Matthew D. McCubbins, "Agenda Power in the Japanese House of Representatives," Japanese Journal of Political Science 1 (May 2000); Gary W. Cox and Mathew D. McCubbins, "Agenda Power in the U.S. House of Representatives, 1877 to 1986," in David W. Brady and Matthew D. McCubbins, eds., Party, Process, and Political Change in Congress: New Perspectives on the History of Congress (Stanford, Calif.: Stanford University Press, 2002); Andrea Campbell, Gary W. Cox, and Mathew D. McCubbins, "Agenda Power in the Senate, 1877 to 1986," in Brady and McCubbins; George Tsebelis and Jeannette Money, Bicameralism (New York: Cambridge University Press, 1997); George Tsebelis, Veto Players: How Political Institutions Work (New York: Russell Sage Foundation, 2002); Barry R. Weingast and William Marshall, "The Industrial Organization of Congress," Journal of Political Economy 91 (October 1988); Michael Laver and Kenneth A. Shepsle, Making and Breaking Government: Cabinets and Legislatures in Parliamentary Democracies (New York: Cambridge University Press, 1996); and William B. Heller, "Bicameralism and Budget Deficits: The Effect of Parliamentary Structure on Government Spending," Legislative Studies Quarterly 22 (July 1997).
}

World Politics 55 (July 2003), 550-78 
ment of items on the agenda, with the "imposition" stage then proceeding either through extraordinary powers wielded by the government (for example, the vote of confidence) or through the marshaling of party discipline by all the partners - or through some combination of the two. ${ }^{2}$ Here we stress that cartels tend to allocate to their own members a controlling share of those official posts to which substantial agenda-setting powers are attached (ministers, committee chairs, speakers, conferees).

It is common to hear that governments in parliamentary systems set the agenda in this two-stage fashion (hammering out, then imposing). We focus here on a presidential system, that of Brazil, and examine how well the cartel thesis holds up in its lower house, the Câmara dos Deputados (Chamber of Deputies). Brazil is a good choice for exploring our thesis, for two reasons. First, it allows the joint tenure of legislative and executive posts (or, more precisely, those who accept cabinet posts can resume their legislative seats at will, upon resigning their portfolios). Second, it has had both majority and minority governments. We can thus look within a single case, with much held constant, to see whether majority government does entail cartelization of the agenda.

Recent studies of the Câmara suggest contrasting answers to this question. On the one hand, Figueiredo and Limongi depict Brazilian politics since the promulgation of the 1988 constitution as operating in a parliamentary mode, with presidents constructing stable support coalitions in the Congress and ruling through them. On the other hand, Ames depicts Brazilian politics as far more fluid, with presidents constructing a series of ad hoc coalitions for different issues and purposes. Although they do not use our terminology, Figueiredo and Limongi's work suggests the existence of agenda cartels, while Ames's suggests their absence. ${ }^{3}$

In our view, Brazil's assembly has the potential to oscillate between parliamentary and shifting-coalitions modes, depending on presidential strategy. Some Brazilian presidents might assemble minority support coalitions in the legislature and choose not to subordinate their agenda

\footnotetext{
${ }^{2}$ On confidence procedures, see John D. Huber, "The Vote of Confidence in Parliamentary Democracies," American Political Science Review 90 (May 1996); and Daniel Diermeier and Timothy J. Feddersen, "Cohesion in Legislatures and the Vote of Confidence Procedure," American Political Science Review 92 (June 1998). On party discipline, see John R. Aldrich and David W. Rohde, "Theories of Party in the Legislature and the Transition to Republican Rule in the House," Political Science Quarterly 112 (September 1997); Gary W. Cox and Keith T. Poole, "On Measuring Partisanship in Roll Call Voting: The U.S. House of Representatives, 1877-1999," American Journal of Political Science 46 (April 2002); James M. Snyder and Tim Grosclose, "Estimating Party Influence on Congressional Roll Call Voting," American Journal of Political Science 44 (January 2000).

${ }^{3}$ Argelina C. Figueiredo and Fernando Limongi, Executivo e Legislativo na Nova Ordem Constitucional (Rio de Janeiro: Editora FGV, 1999); idem, "Presidential Power, Legislative Organization, and Party Behavior in Brazil," Comparative Politics 32 (April 2000); Barry Ames, The Deadlock of Democracy in Brazil: Interests, Identities, and Institutions in Comparative Politics (Ann Arbor: University of Michigan Press, 2001).
} 
power to the coalition's collective leadership. That is, parties in the president's support coalition would have no guaranteed right to veto the placement of bills on the legislative agenda, as their parliamentary counterparts (in majority governments) typically would. Other Brazilian presidents, by contrast, might choose to build a deeper, parliamentarystyle support in the legislature. The president would cement his coalition by distributing positions in his cabinet to key party politicians and coordinating the exercise of his agenda powers with his partners. ${ }^{4}$ In this way the president could combine his own agenda powers with those of a legislative majority and the coalition thus formed could operate along the lines of a majority government in a parliamentary system.

We proceed as follows in the rest of the article. The first sections define what an agenda cartel is, describe how to detect cartels empirically, and provide background information on Brazil's Chamber of Deputies. The following sections provide evidence on the structure of veto power in Brazil and test the cartel thesis. We show that Brazil has experienced only one true majority government, that of Cardoso, since the promulgation of the newly democratic constitution in October 1988. Moreover, it is only under Cardoso that an agenda cartel formed.

\section{The CARTel Thesis}

\section{What Is AN AgENDA CARTEL?}

In all national assemblies of which we are aware, there are certain offices to which extraordinary agenda powers attach. Only the Speaker of the U.S. House of Representatives, for example, can grant recognition for motions to suspend the rules. Only Ministers of the Crown can propose new taxes in the U.K. Only the Brazilian president can unilaterally force legislative action via the presidential urgency procedure (discussed below).

We define an agenda cartel as a set of agents possessing two key properties. First, they collectively hold a controlling share of the agenda-setting offices relevant to a given assembly. Thus, just as an economic cartel collectively monopolizes an economic resource, such as oil, so an agenda cartel collectively monopolizes a legislative resource, agenda-setting offices. Second, the cartel establishes a procedure for agreeing on which proposals will be allowed access to the plenary session. Whether decentralized or centralized, formal or informal, this

\footnotetext{
${ }^{4}$ Sérgio H. Hudson de Abranches, "Presidencialismo de Coalizão: O Dilema Institucional Brasileiro," Dados 31 (February 1988); Ames (fn. 3), 162-67; Octavio Amorim Neto, "Presidential Cabinets, Electoral Cycles, and Coalition Discipline in Brazil," in Scott Morgenstern and Benito Nacif, eds., Legislative Politics in Latin America (New York: Cambridge University Press, 2002); Figueiredo and Limongi (fn. 3, 1999 and 2000).
} 
procedure amounts to investing $\mathrm{k}$ groups within the cartel, $\mathrm{C}_{1}, \ldots, \mathrm{C}_{\mathrm{k}}$, with vetoes over the placement of proposals upon the plenary agenda.

Two subspecies of agenda cartel are worth noting, by way of illustration. First, in parliamentary systems it is often said that each pivotal party in a multiparty majority coalition wields an agenda veto. ${ }^{5}$ In this case the groups $\mathrm{C}_{1}, \ldots, \mathrm{C}_{\mathrm{k}}$ that wield agenda vetoes correspond to the pivotal parties in government. We call this a parliamentary agenda cartel. Second, Cox and McCubbins suggest that any majority of the majority party can veto the placement of items on the floor agenda in the U.S. House of Representatives. ${ }^{6}$ It is the first subspecies of agenda cartel - the parliamentary agenda cartel - that will be relevant in this article.

When a parliamentary agenda cartel exists, it is as if the legislative agenda were set as follows. Whoever wishes may introduce bills. In order for a bill to advance to the plenary session under the current government, however, it must be acceptable to each veto player, $\mathrm{C}_{1}, \ldots, \mathrm{C}_{\mathrm{k}}$.

There are two ways to model these unwritten partisan vetoes. In the simplest model the vetoes are not subject to override. One ignores, in other words, the possibility that $\mathrm{C}_{\mathrm{k}}$ 's coalition partners might send a bill to the floor even after $C_{k}$ has vetoed it, perhaps in the belief that $C_{k}$ is bluffing and will not really bring down the government over this issue. In this model the veto players should never lose (that is, have an unwanted policy change forced upon them). In various more complex models the possibility of overriding vetoes would be more explicity considered and veto players could in some cases lose, but their vetoes would still be valuable. ${ }^{7}$ We prefer the simpler model, which exaggerates the power of the vetoes created in a parliamentary agenda cartel, as the purpose here is to underline the primary issue (there are vetoes), not the secondary issue (that the vetoes might be overridden).

\footnotetext{
${ }^{5}$ By a pivotal party we mean one whose withdrawal would deprive the government of a majority in the assembly. This is the conventional definition in the literature on government formation. See, e.g., Michael Laver and Norman Schofield, Multiparty Government: The Politics of Coalition in Europe (New York: Oxford University Press, 1990).

${ }^{6} \mathrm{Cox}$ and McCubbins (fn. 1).

${ }^{7}$ To briefly illustrate one more complex model, suppose that some members of a cartel "disrespect" a veto issued by one of its members, by cooperating with the opposition if need be. They thereby confront the vetoer with a choice of backing down (allowing the current government to continue and the offensive bill to be considered) or resigning (bringing the current government down, thereby postponing action on the bill until a new government can form). Given complete information (all parties know each other's preferences), a threat to resign would be either transparently credible if the threatening party really would prefer to bring down the government, rather than see the bill passed, or transparently noncredible if not. Thus, allowing "disrespect" and assuming complete information would mean that an agenda cartel might split on some bills, leading to some governing parties being rolled. Even in this model, however, parties in the cartel could veto some bills, in a way they could not had they not formed a cartel. One would thus expect parties' roll rates to be lower when they were in government, all else equal-a proposition for which we provide evidence in Table 2 .
} 


\section{WHAT IS A GOVERNMENT?}

We shall say that a legislative party is "in government" if at least one of its members holds a cabinet portfolio. ${ }^{8}$ A majority (minority) government is one in which cabinet portfolios are distributed to parties that collectively hold a majority (minority) of seats in the assembly.

\section{The CARTEL Thesis}

The cartel thesis holds that if a majority government forms, then it will also constitute an agenda cartel. For present purposes, we advance this thesis simply as an empirical generalization to be tested, rather than deriving it as a conclusion from more primitive assumptions. Its theoretical status is thus similar to the observation that if a multiparty government forms in a parliamentary system, then each party's share of portfolios will closely reflect its share of seats in the assembly. ${ }^{9}$

Characterizing the nature of the government bargaining outcomes that emerge in equilibrium are both the claim that agenda vetoes are distributed to each pivotal party (the parliamentary cartel thesis) and the claim that portfolios in parliamentary systems are distributed proportionally to seat shares. Theoretical models of the governmentformation process should then accommodate these empirical regularities, to the extent that they are empirically validated. A primary purpose of this paper is to see how well the parliamentary cartel thesis extends to the case of Brazil, where it has been claimed that governments form and govern in parliamentary fashion.

\section{IDENTIFYING CARTELS}

How can one test for the existence of an agenda cartel? Some scholars test assumptions about who wields vetoes in a given legislature by examining law production. The notion is that the more veto players and the more divergent their preferences, the harder it will be for them to agree on any significant new laws. We prefer a more direct test hinging on the observation that if a coalition partner $\mathrm{C}$ wields a veto, then $\mathrm{C}$ should never unsuccessfully oppose the passage of a bill. ${ }^{10}$

\footnotetext{
${ }^{8}$ Sometimes in Latin America a legislator belonging to a particular party will take office as a minister purely as an individual, without his or her party's endorsement. We discuss how we handle such cases in a later section.

${ }^{9}$ Eric C. Browne and Mark Franklin, "Aspects of Coalition Payoffs in European Parliamentary Democracies," American Political Science Review 67 (April 1973); Ian Budge and Hans Keman, Parties and Democracy: Coalition Formation and Government Functioning in Twenty States (New York: Oxford University Press, 1990), chap. 4.

${ }^{10}$ Among those examining law production are Döring (fn. 1); Krehbiel (fn. 1); and Tsebelis (fn. 1). Focusing on unsuccessful opposition are Cox, Masuyama, and McCubbins (fn. 1); Cox and McCubbins (fn. 1); and Campbell, Cox, and McCubbins (fn. 1).
} 
Operationally, if a majority of a party votes against a bill that nonetheless passes, we say that the party has been rolled. Think of a legislative train leaving the station and of a party that has tried to stop itbut been run over. Prior to the final passage stage, there are also sometimes clear agenda-setting votes - that is, votes to determine whether the legislature will or will not consider a particular bill in plenary session. We also speak of parties being rolled on these initial agenda-setting motions, when they vote against them but the motion nonetheless passes. If a party wields a veto, it should never be rolled.

Cox, Masuyama, and McCubbins find that governing parties in parliamentary systems typically have positive but small (below 5 percent) roll rates, as majority parties have had in the U.S. House and the Senate since the late nineteenth century. ${ }^{11}$ These empirical findings suggest that the simplest veto model, in which vetoes cannot be overridden, does indeed oversimplify. Thus, rather than take a zero roll rate for all partners as indicating the presence of a parliamentary agenda cartel, we adopt a more pragmatic standard and use 5 percent as the cutoff value defining what a low roll rate is. Theoretically, we are implicitly admitting the possibility that there may be bills that one governing partner dislikes enough to vote against but does not dislike enough to resign over in protest and thus bring down the government.

What if there is no agenda cartel and no party wields a veto? If we assume that all parties can be placed along a traditional left-right scale, so that successful bills necessarily propose to move policy toward the median legislator's ideal point, then we have a very simple expectation: the median party is never rolled, while roll rates increase monotonically both to the left and to the right.

The intuition behind this result is straightforward. The median party cannot be rolled because it is not possible to form a majority that wants to move policy away from the median in a unidimensional model. That roll rates increase to either side of the median can be illustrated by imagining that a particular status quo policy lies between two rightwing parties' median ideal points and that a bill proposing to move policy leftward is passed (see Figure 1). The more extreme party (R2 in the figure) will necessarily vote against the bill, as it seeks to move policy farther away from its ideal; hence, it will be rolled. The more moderate party (R1 in the figure) may vote for the bill, if it is closer to the party's median ideal point than is the status quo. In the case pictured in the

\footnotetext{
${ }^{11}$ Cox, Masuyama, and McCubbins (fn. 1). For the House, see Cox and McCubbins (fn. 1); for the Senate, see Campbell, Cox, and McCubbins (fn. 1).
} 


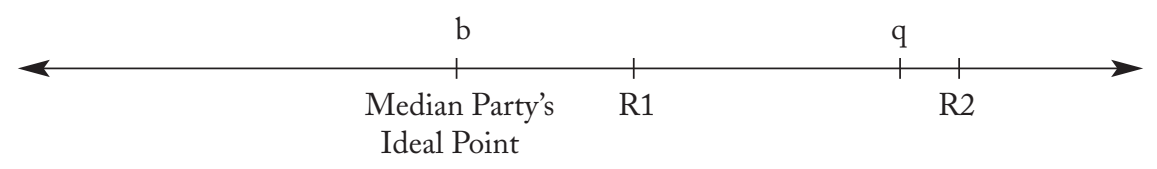

FIGURE 1

An Illustration of How More Extreme Parties Are Rolled More Often

figure, the moderate party is not rolled. Generalizing from this example, one can show that the roll rate of the more extreme party must be higher than that of the more moderate party-and this is true to the left of the median party as well.

Thus, we have a general test for the absence of an agenda cartel. If there is a clear U-shaped pattern in party rolls, viewed across the leftright spectrum, then there cannot be an agenda cartel. ${ }^{12}$

In the specific case of Brazil, we identify cartels as follows. First, we identify the president's nominal support coalition, defined as all parties any of whose members hold cabinet portfolios. We begin with the president because he has such substantial agenda-setting powers in Brazil that no agenda cartel can form without him. ${ }^{13}$ Second, we examine the roll rate of each party in the nominal support coalition (that is, the percentage of bills scheduled or passed against their wishes). If the president has forged a parliamentary agenda cartel, then the roll rate of each party in that cartel will be zero or, more leniently, as low as the observed rate for government parties in parliamentary systems. Third, we examine in greater detail how the president distributed his portfolios. If he indeed sought to forge a parliamentary-style coalition, then one expects each party in the support coalition to wield a share of portfolios comparable to its share of seats. Fourth, we examine the president's relative use of statutes and decrees. If a parliamentary agenda cartel has been formed, then the president should use it, meaning that he will seek statutory or constitutional implementation of his legislative goals,

\footnotetext{
${ }^{12} \mathrm{~A}$ U-shaped pattern in party rolls clearly precludes left-connected and right-connected cartels. But what if a cartel consists only of centrist parties? In this case, we would expect all the parties in the cartel to have near zero roll rates, whereas in the absence of a cartel only the median party would have such a roll rate. Thus, a U-shaped pattern clearly precludes a "centered" cartel only if the parties immediately to the left and right of the median party have significantly higher roll rates than does the median party. This of course may be asking a lot of the data, in the sense that, even if it were true that no cartel existed, there might not be enough policies on which the median party and the party immediately on its right (left) disagreed to generate a significant increase in the latter's roll rate.

${ }^{13}$ Recall that by definition an agenda cartel includes a controlling share of agenda-setting offices. As we shall see, the president has such large powers that it is not possible to create a coalition that excludes him and yet can control the agenda.
} 
rather than decree-based implementation. If a coalition has low roll rates and secures a good representation in the cabinet of a president who seeks statutes rather than decrees, we shall consider it to be a cartel. In some cases, we can also provide qualitative evidence to complement our more systematic data.

\section{BraziL's Legislative Process}

In this section we review Brazil's legislative process. After surveying the basics of the system, we focus on the structure of internal (legislative) and external (presidential) agenda power. Our main points are simple: agenda power is concentrated in Brazil and is delegated to party leaders; however, an external agent - the president-also wields substantial independent power over the agenda.

\section{BASICS}

Brazil has a bicameral legislature. Although the powers of the two chambers are symmetric, we shall consider only the Chamber of Deputies, as roll-call data for the Senate were not available for our time period.

Individual members of the Câmara are entitled to introduce bills. Any legislative initiative is referred to the committee under whose jurisdiction it falls. Committees can approve (totally or partially), amend, reject, or propose wholesale substitutes to the bills submitted for their consideration. The 1988 constitution attempted to strengthen the role of committees by endowing them with the prerogative to enact bills (under some specified circumstances) without reporting them to the floor. Should a bill be either approved or not enacted by the committee, it is referred to the floor for consideration by the full Chamber. Floor amendments to the bill are put to a vote first. Then, the whole bill (project in Brazil's legislative jargon) is voted on globally (em globo, in Portuguese), up or down.

There are three types of votes in the Chamber of Deputies: secret votes, voice votes, and roll-call votes. Secret votes are taken on motions to overturn presidential vetoes, motions to set up investigative committees, and impeachment trials of presidents, legislators, and judges. Voice votes are convenient and frequent but after the result of a voice vote is announced, any deputy can request a quorum count to verify the presence of a majority. A request for a quorum count supported by at least 6 percent of the Chamber membership triggers a roll-call vote. Support by 10 percent of the Chamber membership is required for a separate roll call on amendments. Quorum counts and roll calls are usually requested 
by opposition parties so as to force the majority to make public disclosure of its position. However, there are limits on the opposition's ability to request quorum counts. The Chamber's standing orders allow that a quorum count can be requested only one hour after the result of a previous roll call is proclaimed. This rule is designed to prevent the opposition from paralyzing floor decision-making by requesting quorum counts all the time.

\section{Legislative Agents and Agenda Control}

Despite these unusual constitutional powers, Brazilian committees are relatively weak, often overruled by party leaders' petitions to discharge bills by means of urgency requests ${ }^{14}$ (we will elaborate more on urgency requests below). By contrast, political parties, despite being very weak in the electorate, ${ }^{15}$ are important in the organization of legislative business in the lower house, along with the Mesa Diretora (the Chamber's steering board). ${ }^{16}$ Article 175 of the standing orders stipulates that the Mesa chair (the presiding officer of the Chamber) organizes the legislative agenda in consultation with the so-called College of Leaders. This is the most important decision-making body of the lower chamber. It is composed of leaders of parties commanding at least 1 percent of seats and the government leader (the president is entitled to appoint a deputy to act in his name and to make vote recommendations to the floor). The standing orders stipulate that decisions by the College should be made preferably by consensus. If consensus is not possible, however, decisions are to be made by an absolute majority of votes, each vote weighted by the percentage of seats held by each leader's party. A party leader's signature also carries the weight of her party delegation on a petition to request a roll call or urgent consideration. Such procedural rights to represent their delegations give party leaders considerable control over the floor and help centralize decision making in Brazil's otherwise highly fragmented legislature. ${ }^{17}$

Another rule enshrined in the standing orders that strengthens party leaders and weakens committees concerns "urgency." There are two types of urgency motion: simple urgency and superurgency. ${ }^{18}$ Twothirds of the Mesa membership, one-third of the Chamber member-

\footnotetext{
${ }^{14}$ Carlos Pereira and Bernardo Mueller, "Uma Teoria de Preponderância do Executivo: O Sistema de comissões no Legilsativo Brasileiro,” Revista Brasileira de Ciências Sociais 15 (2000).

${ }^{15}$ Scott Mainwaring, Rethinking Party Systems in the Third Wave of Democratization: The Case of Brazil (Stanford, Calif.: Stanford University Press, 1999), 88-174.

${ }^{16}$ Figueiredo and Limongi (fn. 3, 1999 and 2000).

${ }^{17}$ See Figueiredo and Limongi (fn. 3, 2000), 164-65.

${ }^{18}$ Superurgency is our translation from the Portuguese of what in Brazilian legislative jargon is called urgência urgentíssima.
} 
ship (or party leaders representing this number), or two-thirds of a committee membership can request simple urgency on a bill. For simple urgency to be granted, a simple majority must support it in a voice vote. Simple urgency merely allows a bill to be voted on sometime in the same legislative session (a legislative session spans five months). Moreover, only two bills per session may be considered under simple urgency.

Because of these restrictions, especially the last, simple urgency does not provide a regular means for the opposition to upset the agenda of the governing coalition. On occasion, however, the opposition can exploit the rule. As an example, consider the wealth tax in Cardoso's first presidency. When Cardoso was a left-leaning senator in the late 1980s, he sponsored a bill taxing wealth that was held up in committee for a good while. When Cardoso took the presidency in 1995, supported by a center-right coalition, the leftist opposition decided to challenge him by requesting urgency on his long-forgotten bill. Much to Cardoso's embarrassment, his coalition leaders, who opposed the bill, closed ranks to defeat the request on the floor.

As for the superurgency motion, it must be requested by means of a petition signed by either an absolute majority of the Chamber membership or party leaders representing this number. To be granted, a superurgency petition must be approved by an absolute majority of the Chamber membership in a floor vote. If superurgency is granted on a bill, it is immediately discharged from committee and goes to the top of the floor's voting schedule. ${ }^{19}$ Figueiredo and Limongi report that, of the 514 laws enacted by the Congress in 1989-94, 282 (55 percent) were urgently considered in the Chamber of Deputies. ${ }^{20}$

\section{The Role of The PResident}

Brazil's 1988 constitution gives the president a key role in lawmaking. The president has the right to propose bills and constitutional amendments on any topic, in addition to having exclusive legislative initiative in a host of areas, particularly those pertaining to public administration, tax policy, and the budget. The president also has the prerogative to partially or totally veto bills passed by the Congress (presidential vetoes are overriden by an absolute majority in a joint session of Congress). Furthermore, the president's constitutional prerogative to issue provisional measures (or decree-laws) enables him to exert considerable control over the legislative process.

\footnotetext{
${ }^{19}$ Superurgency appears analogous to "extractive" special rules in the U.S. House, with the Mesa in the role of the rules committee.

${ }^{20}$ Figueiredo and Limongi (fn. 3, 1999), 58.
} 
Provisional measures are presidential decrees with the immediate force of law. Once a provisional measure is issued, the Congress has thirty days to vote on it. If the Congress does not take any action in this period, the provisional measure lapses. In most cases the Brazilian Congress has failed to deliberate promptly on provisional measures. However, a Supreme Court ruling in 1989 authorized the executive to reissue provisional measures that the Congress had not considered in due time. ${ }^{21}$ The executive was quick to seize this opportunity. Not surprisingly, of the 3,412 provisional measures issued between October 1988 and February 1999, only 498 (14.6 percent) were original documents. Only 20 of these 498 original measures were voted down by the Congress ( 9 issued by Sarney, 10 by Collor, and 1 by Cardoso). ${ }^{22}$ Moreover, the executive has been resorting to provisional measures to legislate on all kinds of policy areas in any context, despite the fact that the constitution states that provisional measures should deal only with urgent and relevant matters. For example, even fishing rights in the Amazon River have been regulated by provisional measures. In short, presidential decrees have become a powerful policy-making instrument because they allow the executive to unilaterally change the status quo. ${ }^{23}$

According to Figueiredo and Limongi, "Rights to exclusivity and the power to issue decrees with the immediate force of law give the executive the capacity to control the legislative agenda in both its time and content." ${ }^{24}$ The data presented by the authors show that no less than 86 percent of the bills enacted in 1989-97 were sponsored by the executive.

Finally, the president is constitutionally entitled to request urgent consideration of his legislative proposals. There is no vote on the issue

\footnotetext{
${ }^{21}$ See Argelina C. Figueiredo and Fernando Limongi, "O Congresso e as Medidas Provisórias: Abdicação ou Delegação," Novos Estudos Cebrap 47 (March 1997). Note that in September 2001 the Brazilian Congress enacted a constitutional amendment determining that provisional measures would have to be voted on in sixty days and could be reissued only once.

${ }^{22}$ These figures were culled from Brazil-Senado Federal, Levantamento e Reediçôes de Medidas Provisórias: Dados Atualizados em 28 de Fevereiro de 1999 (Brasília: Senado Federal一Subsecretaria de Informações, 1999).

${ }^{23}$ On the politics of provisional measures in Brazil, see Octavio Amorim Neto and Paulo Tafner, "Governos de Coalizão e Mecanismos de Alarme de Incêndio no Controle Legislative das Medidas Provisórias," Dados 45 (April 2002); Argelina C. Figueiredo and Fernando Limongi, "O Congresso e as Medidas Provisórias: Abdicação ou Delegação," Novos Estudos Cebrap 47 (November 1997); Figueiredo and Limongi 1999 (fn. 3, 1999 and 2000); Jorge Vianna Monteiro, "Condicionamentos Institucionais das Medidas Provisórias," Revista de Administração Pública 34 (June 2000); Timothy J. Power, "The Pen Is Mightier Than the Congress: Presidential Decree Power in Brazil," in John M. Carey and Matthew S. Shugart, eds., Executive Decree Authority (New York: Cambridge University Press, 1998); and Gary Reich, "Executive Decree Authority in Brazil: How Reactive Legislators Influence Policy," Legislative Studies Quarterly 27 (January 2002). On decree powers in a comparative perspective, see John M. Carey and Matthew S. Shugart, "Calling Out the Tanks or Filling Out the Forms?" in Carey and Shugart.

${ }^{24}$ Figueiredo and Limongi (fn. 3, 2000), 156.
} 
of granting urgency to the president. The Chamber of Deputies and the Senate have forty-five days to deliberate on any bill deemed urgent by the president. Should either house fail to meet this deadline, the executive bill is immediately put to a vote. In the event one of the houses amends the bill, the other house has ten days to decide on the amendments. The chambers can take as long as they wish in considering the bill but must complete their consideration of it before moving on to any other matter. ${ }^{25}$ Available evidence shows that 53 percent of the executiveinitiated bills enacted by the Congress in 1989-94 were urgently considered in the lower chamber. In this same period urgently considered executive bills took on average twenty-six days to be shuttled to the Senate. ${ }^{26}$ Unfortunately, it is not known how many urgency requests were actually made by the president himself and how many were made by his legislative allies. At any rate, the grant of urgency has been a key mechanism for expediting deliberation on the executive's legislative agenda.

\section{ROLL RATES IN BRAZIL}

DATA

To identify presidentially led cartels we will analyze roll-call votes on projects and on agenda-setting motions. ${ }^{27} \mathrm{~A}$ roll call on a project is equivalent to a final passage vote in the U.S. The main form of agenda-setting motion is an urgency request; however, we include others as well. ${ }^{28}$

As there are many small parties in the Brazilian Chamber, we focus here on the roll rates only for Brazil's "big seven" parties: the PMDB (Party of the Brazilian Democratic Movement), PFL (Party of the Liberal Front), PSDB (Party of the Brazilian Social Democracy), PT (Workers' Party), РPB (Brazilian Progressive Party), ${ }^{29}$ PDT (Democratic Labor Party), and PTB (Brazilian Labor Party). These seven parties together held approximately 96 percent of lower chamber seats in the 1987-91 legislature, 77 percent in 1991-95, and 83 percent in 1995-99.

\footnotetext{
${ }^{25}$ For further details, see the rules posted at www.camara.gov.br.

${ }^{26}$ Figueiredo and Limongi (fn. 3, 1999), 62-63.

${ }^{27}$ Note that a good deal of information on floor decisions will be lost by focusing on roll calls, because, as mentioned, there are also secret votes and voice votes in Brazil. However, roll calls do constitute a sample of the most controversial decisions made on the floor; Figueiredo and Limongi (fn. 3, 1999).

${ }^{28}$ The agenda-setting votes that we include are urgency requests, petitions to anticipate consideration of a bill, the admissibility of a presidential decree, petitions to extend a legislative session, proposals to dismember a bill, petitions to end a floor debate, petitions to withdraw an urgency request, petitions to withdraw bills from the agenda, proposals to vote on a report on a bill, petitions to nullify the enactment of a bill by a committee, and petitions to give priority to a bill.

${ }^{29}$ The PPB was formed in 1995 as a result of the merger of the PPR and the PP. The PP was created in 1993 by the merger of the PST and PTR. The PPR resulted from the merger of the PDS and the PDC in 1993. For the purpose of simplicity the Figueiredo and Limongi roll-call data bank treats all these rightwing parties as a single party for the whole 1989-99 period. We follow their procedure in this article.
} 
Although the big seven parties are often characterized as mostly clientelistic organizations, many legislative scholars agree on their relative left-right placement. The consensus places the PT on the left; the PDT and PSDB on the center-left; the PMDB in the center; the PTB on the center-right; and the PFL and PPB on the right. ${ }^{30}$

In principle, we would present roll rates for each presidential cabinet as identified by Amorim Neto, examining them to see whether parties in the president's coalition had low roll rates or not. ${ }^{31}$ In practice, not all presidential cabinets lasted long enough to generate a significant number of usable roll calls, so we have combined some adjacent cabinets, when one or more parties served in all of them (under the same president). After combining, the periods we examine are Sarney 3 (that is, Sarney's third cabinet, the dates of which are given in Table 1), Collor 1, Collor 2, Collor $3+4$, Franco 1-5, and Cardoso $1+2 .{ }^{32}$

\section{RESULTS}

Roll rates on project and agenda-setting votes for each party in each presidential cabinet (or set of adjacent cabinets) are displayed in Table 1. The first step is to determine for each cabinet (or set of cabinets) whether all parties consistently in the president's nominal support coalition exhibit low (below 5 percent) roll rates, as expected in the presence of a parliamentary agenda cartel.

By the 5 percent standard, one can clearly reject the notion that a cartel existed under Collor 1, Collor $3+4$, and Franco $1-5 .{ }^{33}$ In the first of these periods, a member of the PMDB held a portfolio and yet

\footnotetext{
${ }^{30}$ We follow Michael Coppedge, "A Classification of Latin American Political Parties," Kellog Institute Working Paper, no. 244 (1997); Figueiredo and Limongi (fn. 3, 1999), chap. 4; Mainwaring (fn. 15); Guillermo Rosas and Elizabeth J. Zechmeister, "Ideological Dimensions and Left-Right Semantics in Latin America" (Paper presented at the meeting of the Latin American Studies Association, Miami, 2000). Were we to use the ideological classification provided by Scott Mainwaring, Rachell Meneguello, and Timothy J. Power, the main change would be the PSDB taking the center position in 1995-98 and the PMDB going to the center-left in this same period; see Mainwaring, Meneguello, and Power, "Conservative Parties, Democracy, and Economic Reform in Contemporary Brazil," in Kevin J. Middlebrook, ed., Conservative Parties, the Right, and Democracy in Latin America (Baltimore: Johns Hopkins University Press, 2000). This would not alter our conclusion, articulated and defended in the text below, that there was a solid presidentially led cartel in this period.

${ }^{31}$ Amorim Neto (fn. 4), 56.

${ }^{32}$ Readers interested in a finer-grained breakdown of the data may contact Octavio Amorim Neto at oamorim@fgv.br.

${ }^{33}$ Note that we are dealing here with the universe of relevant votes, not a sample. From this perspective, we can be sure that these roll rates exceed 5 percent. If one wishes to view the actually observed roll calls as samples from a larger universe of "what might have happened" under the given president, then the issue arises as to whether the observed proportions could have been generated by random sampling from a population with mean 5 percent roll rate. From this perspective, one can reject the null of sampling from a population with mean 5 percent roll rate at the $.14, .06$ and .10 levels, respectively, for Collor 1, Collor $3+4$ and Franco 1-5.
} 
TABLE 1

Roll Rates on Project and Agenda-Setting Votes, per Cabinet(s) and Party in Brazil's Chamber of Deputies

(1989-98)

\begin{tabular}{|c|c|c|c|c|c|c|c|c|}
\hline \multirow[b]{2}{*}{ Presidential Cabinet(s) ${ }^{\mathrm{a}}$} & \multirow{2}{*}{$\begin{array}{c}\text { Number } \\
\text { of } \\
\text { Roll Calls }\end{array}$} & \multicolumn{7}{|c|}{ Parties $^{\mathrm{b}}$} \\
\hline & & $P T$ & $P D T$ & $P S D B$ & $P M D B$ & $P T B$ & $P F L$ & $P P B$ \\
\hline Sarney 3 (1/90-3/90) & 18 & 88.9 & 77.8 & 38.9 & $\underline{0}$ & 16.7 & $\underline{5.6}$ & 11.1 \\
\hline Coll & 9 & 100 & 100 & 33.3 & $\underline{22.2}$ & 0 & $\underline{0}$ & 0 \\
\hline Collor $2(10 / 90)-1 / 91)$ & 2 & 100 & 100 & 50 & 0 & 0 & $\underline{0}$ & 0 \\
\hline Collor $3+4(2 / 91-10 / 92)$ & 38 & 73.7 & 52.6 & 36.8 & 5.3 & 10.5 & $\underline{15.8}$ & 23.7 \\
\hline Franco $1-5$ (10/92-12/94) & 25 & 72.0 & 52.0 & $\underline{8.0}$ & $\underline{4.0}$ & 16.0 & $\underline{16.0}$ & 20.0 \\
\hline Cardoso $1+2(1 / 95-12 / 98)$ & ) 161 & 88.2 & 79.5 & $\overline{1.8}$ & $\underline{3.1}$ & $\underline{4.3}$ & $\underline{1.8}$ & 6.2 \\
\hline
\end{tabular}

${ }^{a}$ Collor was removed from office on corruption charges in October 1992, having been replaced by his vice mate Franco. The president's term was reduced from five to four years in 1994. That is why Sarney served for five years, while Cardoso served for four in his first term. Cardoso was elected for a second four-year term in October 1998.

${ }^{\mathrm{b}}$ Underlining indicates that a party was in the president's nominal support coalition.

the party's roll rate exceeds 20 percent-over four times higher than the highest figure for a governing party in any parliamentary system we know, except for cases of minority government. In the last two of these periods, the PFL held portfolios and yet its roll rate exceeds 15 percent. Sticking strictly to the 5 percent criterion, one can also reject the notion that Sarney organized a cartel in his third cabinet (Sarney 3), although here the PFL's roll rate (5.6 percent) is close enough to the (admittedly rough) threshold that additional information is needed before one can reach a firm conclusion. Finally, Cardoso $1+2$ passes the first test, in that no party holding portfolios throughout these cabinets had roll rates above 5 percent. The only exception is the PPB, which joined Cardoso's cabinet only in April 1996 and whose roll rate is 6.2 percent. We ignore Collor 2 henceforth, as it spans only a few months and entails only two roll calls.

Consider next whether U-shaped patterns appear in the party roll rates, as would be expected in the absence of a parliamentary cartel. Surveying the data in Table 1, U-shaped patterns appear only in Sarney 3, Collor $3+4$, and Franco 1-5. Pooling all the data from these three periods, the Spearman correlation between a party's ordinal distance from the PMDB and its roll rate is .93 (for the PMDB and all parties to the left) and .70 (for the PMDB and all parties to the right). Both correlations are significant at the .01 level. Winning coalitions in these periods were most often right connected; that is, the winning parties 
consisted of all those to the right of a certain point on the left-right spectrum. However, left-connected winning coalitions, consisting of all those to the left of a given point, also appeared with some frequency. This is consistent with the supposition that presidents chose different allies on different issues, as best suited their immediate needs, or with the supposition that legislative initiatives came from both the left and the right, with some of each succeeding, or both.

All told, only one period, Cardoso $1+2$, clearly satisfies our initial criteria for identifying the existence of an agenda cartel. In this period the parties PSDB, PMDB, PTB, and PFL were continuously in government and all had roll rates below 5 percent. Moreover, there is no systematic trend in their roll rates across the ideological spectrum. The opposition parties, by contrast, have quite high roll rates that increase with distance from the median party.

Having looked at roll rates, we next turn to two other clues as to the president's legislative strategy. If the president has decided to form a stable legislative majority and govern through it, then one should find that he tends (1) to construct his cabinet out of partisan rather than technocratic materials and also (2) to prefer standard lawmaking procedures to decrees.

\section{CABinet Construction}

The appointment of party politicians to the cabinet has been considered the president's key instrument for building legislative support in Brazil. ${ }^{34}$ We claim that the better a party's representation is in the cabinet, the lower its roll rate will be. This might follow because cabinet positions are bribes that buy parties' votes or because cabinet positions indicate who the president's legislative partners are, with each partner able - as in a parliamentary government - to veto objectionable legislation.

To measure a party's representation in the cabinet, we employ two different statistics. Our first measure is Cabinet Time per Seat. For example, imagine a cabinet with twenty ministries. If a given party heads one ministry the whole year and another ministry during half of the year, the cabinet time spent by the party is $(365+1 / 2 * 365) /(20 * 365)=0.075 .{ }^{35}$

\footnotetext{
${ }^{34}$ Ames (fn. 3), 162-67; Amorim Neto (fn. 4); Figueiredo and Limongi (fn. 3, 1999).

${ }^{35}$ Data on the party affiliation (if any) of cabinet ministers were culled from Alzira Alves de Abreu, Israel Beloch, Fernando Lattman-Weltman, and Sérgio Tadeu de Niemeyer Lamarão, Dicionário Histórico-Biográfico Brasileiro Pós-1930, 5 vols. (Rio de Janeiro: Editora FGV, 2001), and provided by Antônio Octávio Cintra and José L. M. Dias. Additional sources include: for Sarney: Keesing's
} 
Dividing this figure by the legislative size of the party in the lower chamber gives the Cabinet Time per Seat. ${ }^{36}$

Cabinet time, however, tells us about only the bare bones of parties' representation in the executive branch. To flesh this out, we consider the budget resources allocated to parties by presidents, using an indicator devised by Amorim Neto and Santos. ${ }^{37}$ This measure counts the percentage of time a party heads each ministry per year and multiplies it by the percent share of the civilian budget spent by each ministry in the year. The values are then added up. For example, suppose a party headed ministry $\mathrm{X}$ the whole year, and ministry $\mathrm{Y}$ during half of the year. If ministry $X$ spent 20 percent of the civilian budget, and ministry Y 10 percent, then the party was allocated $20 \%+10 \% * 1 / 2=25 \%$ of the civilian budget in the year Y. Dividing this figure by the party's legislative seat share yields our second measure of cabinet representation, Budget Share per Seat. ${ }^{38}$

The dependent variable is the yearly number of rolls of each of the seven big parties in 1989-98, thus generating a sample with $7^{*} 10=70$ observations. As our explanandum is a frequency count variable, we ran an extended beta-binomial model. ${ }^{39}$ Given the panel structure of the sample, we included the first-order lag of the dependent variable on the right-hand side of the equation to control for autocorrelation in the residuals. ${ }^{40}$ We also include six dummies to control for the parties' fixed effects, using the PMDB as the baseline. These dummies allow us to check whether a party's ideological distance from the center (which we know ordinally from conventional left-right placements of the parties) is positively associated with its roll frequency.

Table 2 displays our results, which support two main conclusions. First, the better is a party's cabinet representation-measured either by

Contemporary Archives 31, no. 6 (1985), 33642-50; Veja (a weekly magazine) (February 12, 1986), 16-21; Veja (January 11, 1989), 34-36; for Collor: Veja (March 14, 1990), 26-31; Veja, (April 15, 1992), 18-26; for Franco: Veja (October 7, 1992), 34-49; Jornal do Brasil (a Rio de Janeiro-based daily newspaper), August 20, 1993, 2; Jornal do Brasil, August 21, 1993, 4; Jornal do Brasil, August 29, 1993 , 12; for Cardoso: Istoé (a weekly magazine) (January 4, 1995), 21-22.

${ }^{36}$ Note that, given frequent party jumping in Brazil, we used the yearly legislative size of the parties to calculate the cabinet time per seat.

${ }^{37}$ Octavio Amorim Neto and Fabiano Santos, "The Executive Connection: Presidentially Defined Factions and Party Discipline in Brazil," Party Politics 7 (April 2001).

${ }^{38}$ Data on budgetary expenditures in 1993-98 were provided by the Secretaria de Orçamento Federal (Federal Budget Office) upon e-mail request. For the 1989-92 period the source was BrazilMinistério da Fazenda, Balanço Geral da União, vol. 2 (Brasília: Secretaria do Tesouro Nacional, n.d.).

${ }^{39}$ Bradley Palmquist, "Analysis of Proportions Data" (Manuscript, Vanderbilt University, 1999, available at http://www.vanderbilt.edu/psci/palmquist).

${ }^{40}$ Because we include a lag, the number of observations falls to sixty-three. All our results are qualitatively similar if no lags are included. 
TABLE 2

Extended-Beta Binomial Models for the Yearly Roll Frequency of the Big Seven Parties ${ }^{a}$

\begin{tabular}{|c|c|c|}
\hline \multicolumn{3}{|c|}{ Dependent Variable: Yearly Roll Frequency } \\
\hline Independent Variables & Model 1 & Model 2 \\
\hline \multicolumn{3}{|l|}{ Beta } \\
\hline Lagged Roll & $\begin{array}{l}.022 \\
(.014)\end{array}$ & $\begin{array}{l}.019 \\
(.012)\end{array}$ \\
\hline Cabinet Time per Seat & $\begin{array}{r}-.452^{*} \\
(.261)\end{array}$ & \\
\hline Budget Share per Seat & & $\begin{array}{c}-.969^{* * * *} \\
(.280)\end{array}$ \\
\hline PT & $\begin{array}{l}3.769^{\text {***** }} \\
(.550)\end{array}$ & $\begin{array}{l}3.928^{* * * *} \\
(.450)\end{array}$ \\
\hline PDT & $\begin{array}{l}3.167^{* * * *} \\
(.517)\end{array}$ & $\begin{array}{l}3.280^{\text {**** }} \\
(.471)\end{array}$ \\
\hline PSDB & $\begin{array}{l}.904^{*} \\
(.516)\end{array}$ & $\begin{array}{l}1.235^{* *} \\
(.487)\end{array}$ \\
\hline РТВ & $\begin{array}{l}.711 \\
(.523)\end{array}$ & $\begin{array}{l}.781 \\
(.492)\end{array}$ \\
\hline PFL & $\begin{array}{l}.216 \\
(.540)\end{array}$ & $\begin{array}{l}1.126^{* * *} \\
(.545)\end{array}$ \\
\hline РPB & $\begin{array}{l}.608 \\
(.501)\end{array}$ & $\begin{array}{l}.563 \\
(.464)\end{array}$ \\
\hline Gamma & $.044^{* *}$ & .024 \\
\hline Constant & $(.018)$ & $(.015)$ \\
\hline $\mathrm{N}$ of observations & 63 & 63 \\
\hline Log-likelihood & -511.755 & -507.482 \\
\hline Pseudo $R^{2}$ & .450 & .455 \\
\hline
\end{tabular}

${ }^{*} * * * 0.01 ;{ }^{*} p>0.05 ;{ }^{*} p>0.1$; link function is logit

${ }^{a}$ Standard errors are indicated in parentheses.

Cabinet Time per Seat or Budget Share per Seat-the lower is its frequency of rolls per year. The former effect (which takes account only of time spent in the cabinet) is statistically significant at the .10 level; the latter (which weights each ministry by its budget share), at the .01 level. Second, the greater the ideological distance of a party from the center, the higher its roll rate tends to be. This effect is stronger for the leftwing than for the right-wing parties because at least one right-wing party was always represented in the cabinet (the PFL served on the cabinet every year in 1989-99); and two of the four presidents were right of center (Sarney and Collor) - thus insulating to a great extent even opposition right-wing parties from unwanted policy proposals. 


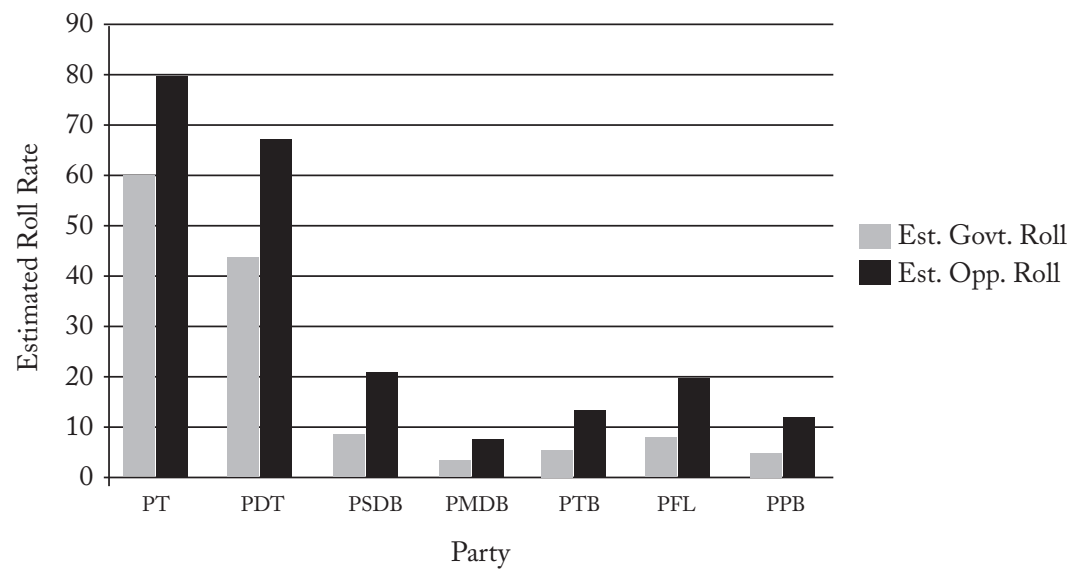

FIGURE 2

The Substantive Impact of Budget Share Per Seat

There is a good reason to prefer the Budget Share per Seat variable to the less informative Cabinet Time per Seat: when we include both variables in the analysis, the coefficient on Budget Share per Seat is largely unaffected (and retains its significance), while that on Cabinet Time per Seat becomes small and insignificant.

The substantive impact of variations in a party's Budget Share per Seat is illustrated in Figure 2, which arrays the seven main parties from left to right along the horizontal axis. Two different roll rates are plotted along the vertical axis: first, the roll rate that the model predicts, if the party's budget share per seat is zero (it is not in government at all); second, the roll rate that the model predicts, if the party's budget share per seat is unity (that is, it gets a budget share equal to its seat share). ${ }^{41} \mathrm{We}$ shall call these two roll rates the "opposition" and "government" roll rates, respectively. Two things can be seen from the figure.

First, each party's predicted opposition roll rate (when its budget share per seat is zero) is higher than its predicted government roll rate (when its budget share per seat is unity). Subtracting each party's government roll rate from its opposition roll rate, the median figure is 11 percent. Averaging across the seven parties, a party is predicted to be

\footnotetext{
${ }^{41}$ One might argue that a budget share per seat of unity is too low to reflect full membership in the cabinet. After all, if only a fraction of the parties in the Chamber get into government and they divide the full budget among themselves, each will have a higher-than-unity budget share per seat. However, Brazilian cabinets always contain nonparty ministers, who take up a certain portion of the budget. Thus, a value of unity does reflect a "full" membership in the cabinet.
} 
rolled 63 percent more often when in the opposition than when in government. ${ }^{42}$

Second, roll rates tend to increase to the right but especially to the left. The only exception to this pattern, in model 2, concerns the PPBwhose predicted roll rates are lower than those of two parties to its left: the PTB and PFL. This unexpected result may stem from the fact that the label PPB in the Figueiredo and Limongi roll-call data bank is an artificial conflation of the labels of four other parties (PDS, PPR, PP, and PDC) that in different moments in time merged in pairs until they finally fused into the PPB in 1995. Such a conflation is bound to overstate the conservatism of some of these legislative cohorts, particularly that of the PDC and PP, which are defined by Coppedge and Mainwaring as center-right rather than rightist parties. Ignoring the PPB, the other six parties "scale" perfectly. ${ }^{43}$

\section{Choice of Policy Instrument}

We now turn to the second dimension of the president's legislative strategy, his choice of policy-making instrument. In Brazil this choice is between what we call standard lawmaking procedures (statutes, complementary laws, and constitutional amendments), on the one hand, and decree-laws, on the other.

If the president is able to form a legislative cartel, then he will typically have enough political support to pursue his legislative agenda by standard lawmaking procedures, rather than by decrees. If the president is unable or unwilling to form a cartel, then his weak legislative support will predispose him to govern by a unilateral policy-making instrument, that is, decrees. ${ }^{44}$

To operationalize the degree to which presidents seek statutory, complementary, or constitutional laws rather than decree-laws, Table 3 also provides the number of statutory bills, bills of complementary laws, constitutional amendments, and original decree-laws initiated by the executive in each period. The last column in Table 3 displays the ratio of all standard lawmaking initiatives of the executive (statutory bills + bills of complementary laws + constitutional amendments) to the total

\footnotetext{
${ }^{42}$ The increase in the roll rate is expressed here as a percentage of the government roll rate.

${ }^{43}$ Coppedge (fn. 30); Mainwaring (fn. 15).

${ }^{44}$ To approve a complementary law requires an absolute majority of the Chamber`s membership, whereas the approval of statutes only takes a majority of the voting deputies. Thus, it is harder to pass complementary laws than statutes. Constitutional amendments are even harder to pass: they require a 60 percent majority of the Chamber's membership.
} 
TABLE 3

Executive-Initiated Statutory Bills, Bills of Complementary Laws, Constitutional Amendments, and Decree-Laws Per Presidential Cabinet(s)

\begin{tabular}{|c|c|c|c|c|c|}
\hline $\begin{array}{l}\text { Presidential } \\
\text { Cabinet(s) } \\
\end{array}$ & $\begin{array}{c}\text { Statutory } \\
\text { Bills } \\
(S B)\end{array}$ & $\begin{array}{l}\text { Bills of } \\
\text { Comple- } \\
\text { mentary } \\
\text { Larws } \\
\text { (CL) }\end{array}$ & $\begin{array}{l}\text { Constitu- } \\
\text { tional } \\
\text { Amendments } \\
(C A)\end{array}$ & $\begin{array}{c}\text { Decree- } \\
\text { Laws } \\
\text { (DL) }\end{array}$ & $\begin{array}{c}\text { Index of } \\
\text { Standard Legislative } \\
\text { Initiatives } \\
S L I=(S B+C L+C A) / \\
(S B+C L+C A+D L)\end{array}$ \\
\hline $\begin{array}{l}\text { Sarney } 3 \\
\quad(1 / 90-3 / 90)\end{array}$ & 142 & 15 & 0 & 109 & 0.59 \\
\hline $\begin{array}{l}\text { Collor } 1 \\
\qquad(3 / 90-10 / 90)\end{array}$ & 37 & 1 & 0 & 56 & 0.40 \\
\hline $\begin{array}{l}\text { Collor } 2 \\
\quad(10 / 90)-1 / 91)\end{array}$ & 43 & 3 & 0 & 18 & 0.72 \\
\hline $\begin{array}{l}\text { Collor } 3+4 \\
\quad(2 / 91-10 / 92)\end{array}$ & 259 & 19 & 2 & 11 & 0.96 \\
\hline $\begin{array}{l}\text { Franco } 1-5 \\
\quad(10 / 92-12 / 94)\end{array}$ & 262 & 25 & 3 & 152 & 0.66 \\
\hline $\begin{array}{l}\text { Cardoso } 1+2 \\
\quad(1 / 95-12 / 98)\end{array}$ & 484 & 48 & 30 & 158 & 0.78 \\
\hline
\end{tabular}

SouRCE: Brazil-Senado Federal (1999) (www.senado.gov.br); data provided by Argelina C. Figueiredo and Fernando Limongi.

legislative input of the executive per period, what we call the index of standard legislative initiatives (SLI). SLI varies between 0 and 1 . The higher the score on SLI, the more presidents prefer to make policy via standard lawmaking procedures.

As can be seen, the three lowest SLI values occur for the periods Sarney 3, Collor 1, and Franco 1-5. In each of these periods, as we have seen, there is a governing party with a roll rate above our 5 percent threshold. In the first and last of these periods, there is a U-shaped pattern on rolls. Thus, several signs point to the lack of a consistent presidentially led cartel in these periods.

The second-bighest value for SLI occurs in Cardoso $1+2$. Moreover, under Cardoso the PFL and PSDB had their highest scores on Budget Share per Seat in the whole 1989-98 period; and we find the greatest stability in cabinet tenure of all the post-1988 presidencies. Thus, Cardoso $1+2$ is the only period in which we observe consistency between the design of the cabinet (partisan), presidential policy-making strategy (statutory/constitutional), and a strong cartel in project and agenda- 
setting votes (with low roll rates for all parties in the Cardoso coalition)..$^{45}$

Putting aside the cases clearly lacking a cartel (Sarney 3, Collor 1, and Franco 1-5) and the case clearly exhibiting a cartel (Cardoso $1+$ 2 ), we are left with a somewhat odder case, Collor $3+4$. Although this period exhibits a governing party with a high roll rate (the PFL) and a U-shaped pattern in roll rates, nonetheless the president relied heavily on statutes. Collor signed only 11 decrees but sponsored 259 statutes, 19 complementary laws, and 2 constitutional amendments. This period's score on SLI (0.96) is thus the highest for our entire period.

Let us digress briefly to consider this puzzling case in more detail. Note first that Collor actually tried to cooperate with some legislative parties by means other than cabinet appointments. According to Power:

\begin{abstract}
With Collor's personal intervention in December [1990], Passarinho [a conservative senator] finally succeeded in creating the desired progovernment bloc in Congress. This was the first such bloc created under the Constitution of 1988, which explicitly permitted the formalization of legislative coalitions [...]. Called the Movimento Parlamentar Social Liberal [Social Liberal Parliamentary Movement] but known simply as Bloco, it was based formally on the PFL and PRN, but also received informal support from the PDS [later the PPB], PTB, PDC, and several microparties. ${ }^{46}$
\end{abstract}

The Social Liberal Parliamentary Movement was cemented with the distribution of pork, particularly for the PFL deputies. ${ }^{47}$ While the Parliamentary Movement certainly provided Collor with a firmer legislative basis than the one he had in 1990, the Bloco's parties never

\footnotetext{
${ }^{45}$ It could be argued that if we also look at the number of decrees that were simply reissued or were reissued with modifications in their texts, the nice consistency between cabinet design and presidential policy-making found in Cardoso $1+2$ would evaporate. After all, Cardoso simply reissued 1,997 decrees and reissued 453 decrees with their texts modified, while Sarney reissued 20 and modified 2, Collor re-emitted 20 and changed 21, and Franco reissued 326 and modified 37. Presidents have to reissue decrees when Congress does not vote on them in time. According to Amorim Neto and Tafner (fn. 18), in general, Congress does not promptly deliberate on decrees so as not to waste its time on less relevant issues. Seventy percent of the decrees deal with minor questions relating to the grant of credits, transfers of budgetary appropriations, civil servants, and the organization of public administration. So when the executive reissues a decree, this means that the Congress is implicitly delegating the executive powers to legislate on issues toward which the legislative majority is indifferent. Such delegation is more likely precisely when the president and the majority have colluded under a coalition agreement or, in the terms of this article, have formed a presidentially led cartel. As for the reissuance of decrees with their texts modified, Amorim Neto and Tafner argue that this is a mechanism that allows deputies to make ex post amendments to original decrees, thus helping better coordinate the preferences of presidents and legislators who have colluded under a coalition agreement. The modifications effected in original decrees are designed precisely to address the demands pressed by the government's allies and not those of the opposition. As Cardoso led a strong cartel, this explains in part why he had the highest average of reissued decrees with modified text.

${ }^{46}$ Power (fn. 23), 194.

${ }^{47}$ Ames (fn. 3), 176-80.
} 
commanded a legislative majority in 1991-92. So where could Collor obtain legislative support to approve 93.0 percent of the statutes he sent to Congress? ${ }^{48}$

The answer appears to be that Collor struck a separate deal with the PDT. Indeed, the cooperation between Collor and the PDT was publicly avowed and cemented by side payments. ${ }^{49}$ According to newspaper reports, the state of Rio de Janeiro, then governed by the PDT's main leader, Leonel Brizola, received 576 million dollars in federal grants in 1991 as a consequence of the Collor-PDT alliance.$^{50}$ In return, the PDT's leaders in the Chamber of Deputies went from agreeing with Collor's vote recommendations 4.3 percent of the time in Collor 1 and 2, to 25.5 percent of the time in Collor $3+4$. Interestingly, with the support from the PDT, which held 9.1 percent of lower chamber seats, the Social Liberal Parliamentary Movement (PFL + PRN + PDS + PTB + PDC $=44.2 \%)$ could provide Collor with a minimal winning majority of 53.3 percent of seats.

However, given that Brazilian parties are not perfectly disciplined, such a majority could never be taken for granted by Collor. The PMDB was still the pivotal party and Collor would have to come to terms with it. What the PMDB wanted the most was to have Collor stop issuing decrees as he did in 1990. In April 1991 the Chamber of Deputies nearly approved a bill sponsored by a PMDB deputy, Nelson Jobim, designed to place limits on presidential decree powers. Although the Jobim bill was defeated (by a very small margin), its message was clear and seems to have made an impression on Collor and his advisers. ${ }^{51}$ On top of it in August 1991 the Chamber of Deputies voted down a presidential decree granting pay increases to public servants and the military. On this occasion the PFL, considered Collor's staunchest supporter, joined the opposition.

In short, the Câmara, in practical terms, broke Collor's decree powers. He was thus left with only the alternative of using standard legislative procedures-explaining the very high SLI score for Collor $3+4$. To achieve a high approval rate for his statutory bills, Collor abandoned his most-preferred (and conservative) policies, as demonstrated by Ames, and distributed pork both to his main supporters (the PFL) and to a strange bedfellow (the PDT). ${ }^{52}$ What he did not do was to turn the Social Liberal Parliamentary Movement into an effective presidentially led cartel.

\footnotetext{
${ }^{48}$ Data provided by Argelina C. Figueiredo and Fernando Limongi.

${ }^{49}$ See "Brizola promete ajudar Collor," O Globo (Rio de Janeiro), March 8, 1991.

${ }^{50}$ See "Uma chuva de dinheiro no Rio," O Globo, May 23, 1991.

${ }^{51}$ Power (fn. 23), 211.

${ }^{52}$ Ames (fn. 3), 192-94.
} 
Nominal Majorities, Real Majorities, and the Cartel Thesis

Were any of the presidential cabinets we have studied majority governments? To answer this question, we first identify the nominal support coalitions of each president - the set of all parties any of whose members accept portfolios under the president. The share of seats held by the nominal support coalition for each president is easily calculated. Indeed, Deheza provides such figures for a variety of Latin American cases, including Brazil..$^{53}$ For that matter, one can readily calculate the nominal support coalitions of prime ministers in parliamentary systems. On the basis of these figures, one can divide presidents (and premiers) into those who command a nominal majority and those who do not.

Nominal support coalitions are of interest for present purposes only to the extent that they entail a trade, with the chief executive handing out portfolios in exchange for his legislative partners' delivery of a reliable bloc of votes in the assembly. The appointment of a legislator from a given party does not, however, invariably indicate such a trade. In Latin American presidential systems, for example, legislators sometimes accept portfolios as individuals, rather than as leaders of their respective parties. One would not expect a given party to offer reliable support to a president, merely because one or two of its members had accepted portfolios as individuals. Thus, it is important - both in general and in the particular case of presidential systems - to discount ministerial appointments that are known not to be the cement of an alliance.

In Brazil the newspapers and the entries in Abreu et al. discuss the appointment of each minister, indicating whether the minister takes office as a representative of his party (and thus as part of a deal to deliver that party's votes to the president on a consistent basis) or as a mere individual. ${ }^{54} \mathrm{We}$ have read the entries and newspaper accounts of each ministerial appointment in our time period and thus can identify each minister who was "endorsed" or "recommended" by his party and each who was not.

One way to discount the support of a party is to calculate the proportion of its ministers who are endorsed. If all its ministers are endorsed, this is consistent with the existence of a trade of portfolios for votes. If none of its ministers is endorsed, this is inconsistent with the existence of such a trade-off. Thus, instead of summing the seat shares of all parties with any members having portfolios, one discounts each

\footnotetext{
${ }^{53}$ Grace Ivana Deheza, "Gobiernos de Coalición en el Sistema Presidencial: America del Sur" (Ph.D. diss., European University Institute, Florence, 1997).

${ }^{54}$ Abreu et al. (fn. 35).
} 
party's seat share by the proportion of its ministers who are endorsed and then sums the resulting figures. This is one way to calculate the effective support of a president.

Another way to discount party support is to examine how each party's share of portfolios compares with its share of seats in the assembly, among those parties with endorsed ministers. If a party is getting a share of portfolios that is proportionate to its share of seats (among the governing parties), then this echoes the parliamentary pattern of strict proportionality between seat and portfolio shares in the government and provides additional evidence consistent with a portfolios-for-votes trade.

Whether one discounts each party's seat share by the proportion of its ministers who are endorsed or by the ratio of each party's portfolio share to its seat share (among governing parties), one arrives at the same conclusion. By either definition of effective support, only Cardoso 2 is a real majority government. Several previous periods, such as Sarney 3 and Franco 1-5, exhibit nominal majorities. Once one discounts those parties with subpar representation in the cabinet-assuming that they would also deliver subpar portions of their own votes-all governments prior to Cardoso 2 are minority governments. ${ }^{55}$

Focusing on "real" majorities, there is a perfect correlation: no minority government in Brazil formed an agenda cartel; only the one majority government did form such an agenda. ${ }^{56}$ Whether this pattern will continue in the future is, of course, unknown. But for now the pattern is clear.

\section{Discussion: CARTEls AND Successful Governance}

Does the fact that Cardoso constructed an agenda cartel and ruled through it in a fashion analogous to many prime ministers mean that

\footnotetext{
${ }^{55}$ Yet another way in which one might decide whether a particular president has majority support is more behavioral and yields the same conclusion. Using the data provided by Amorim Neto (fn. 4), 64, we can calculate a president's "average support level" as the seat share of his nominal support coalition, times the average percentage of his nominal supporters who actually vote in accordance with the recommendations of the government leader in the assembly on critical roll calls (that is, those on which at least 60 percent of the legislators vote and at least 20 percent of those voting are in the minority). If the parties in the nominal support coalition offer completely reliable support, then the average support level will equal the nominal coalition size; otherwise, the average support level will fall short of that size, reflecting the absence of a successful deal to trade portfolios for votes. Calculating the average support level for each presidential cabinet in our period, and defining majority governments as those with average support in excess of 50 percent, we find that —again—only Cardoso 2 qualifies as a majority government.

${ }^{56}$ We continue to ignore Collor 2, which lasted only a few months and generated only two usable roll calls. Suppose one thought that Collor 2 did constitute an agenda cartel (since the only governing party, the PFL, has a zero roll rate). There are a variety of reasons to doubt this judgment but, even if one arrived at it, one would merely have found a case of a minority government that did cartelize the agenda, as frequently occurs in the European cases. This would not conflict with the cartel thesis.
} 
he was powerful or successful? Any chief executive who fashions a parliamentary agenda cartel must bargain with his partners for every major piece of legislation. Whatever the chief executive's level of control over those internal negotiations - low, medium, or high-once a bargain within the cartel has been struck, the implementation of that bargain within the assembly will typically entail enough support from the governing partners to pass the relevant bill. ${ }^{57}$ Thus, one can no more deduce presidential power in Brazil from the high cohesion of the president's support coalition than one can deduce prime ministerial power in Japan from the high cohesion of the government's troops. Nevertheless, finding that Cardoso created an agenda cartel does mean that in one important way he acted like a premier. Moreover, there is no reason to suppose that he was outside the normal range of success of premiers. This is not to disagree with specific examples of how and why Cardoso had trouble with his coalition, such as Samuels's careful explanation of the high price Cardoso had to pay for the Plano Real. ${ }^{58} \mathrm{It}$ is just to suggest that premiers have also had to pay high prices in their countries for their legislative accomplishments. To make any headway in comparing Cardoso's success with that of another chief executive, one would have to know much more.

Among other things, it would help to know why each chief executive chose to form a majority government, even at the cost of respecting each partner's veto, rather than forming a minority government and have more flexibility in forming tailor-made support coalitions for each issue. In the next section, we briefly consider the choice of minority/ majority government - first in the abstract, then in the particular case of Brazil.

\section{Discussion: On ChOOSING MinORITY (OR MAJORITY) GOVERNMENT}

It is beyond the scope of this article to provide a general model of the conditions under which minority rather than majority governments emerge in Brazil. We can, however, review two prominent studies of minority government and see how the factors they identify play out in the Brazilian case.

Strom provides the best-known study of minority governments, focusing on European parliamentary cases and arguing, in a nutshell, that

\footnotetext{
${ }^{57}$ For, if sufficient support is not lined up, then what was the point of the bargaining to begin with?

${ }^{58}$ David Samuels, Ambition, Federalism, and Legislative Politics in Brazil (New York: Cambridge University Press, 2003), chap. 9.
} 
minority governments emerge when some parties find it electorally costly to join a government with whose policies they will inevitably be associated and thus prefer to await the next elections. For such parties, accepting current portfolios threatens to diminish their future share of votes, seats, and portfolios, while eschewing current portfolios promises to maintain or even boost their future share of votes, seats, and portfolios. The tendency to refuse current government portfolios is even stronger when opposition parties enjoy better procedural rights (such as rights to a proportional share of chairs of the powerful committees in the Scandinavian parliaments). ${ }^{59}$

Cheibub provides a recent study of minority governments in presidential systems. ${ }^{60} \mathrm{He}$ finds that more parliamentary parties, bicameralism, and nonconcurrent elections all boost the probability of minority government. One way to interpret his empirical findings is as follows. Majority governments must be negotiated. The larger the effective number of parties, the more separate actors who must be brought into those negotiations in order to form a majority, and hence the more likely those negotiations are to break down. Similarly, bicameral systems essentially double the number of players at the table, again complicating negotiations. ${ }^{61}$ Finally, nonconcurrent presidential and legislative elections deprive negotiators of one natural set of tools ( $\mathrm{mu}-$ tual endorsements) to build a majority.

One variable that Cheibub does not include but that fits in with the same line of argument is the internal cohesion of the parties in a given polity. Morgenstern has noted that factions and mavericks sometimes play an independent role in Latin American legislatures. ${ }^{62}$ Factionalization (or atomization) would again multiply the number of players at the table during negotiations, making the formation of majority governments more difficult.

In sum, Cheibub's work focuses on the sheer number of distinct agents who would need to have a seat at the table during the negotiations to form a majority government; he predicts that the greater this number, the less likely the negotiations are to succeed. If negotiations

\footnotetext{
${ }^{59}$ Kaare Strom, Minority Government and Majority Rule (New York: Cambridge University Press, 1990).

${ }^{60}$ José Antonio Cheibub, "Minority Governments, Deadlock Situations, and the Survival of Presidential Democracies," Comparative Political Studies 35 (April 2002).

${ }^{61}$ Compare James Druckman and Michael F. Thies, who find that bicameralism significantly decreases the duration of governments in parliamentary systems; see Druckman and Thies, "The Importance of Concurrence: The Impact of Bicameralism on Government Formation and Duration," American Journal of Political Science 46 (September 2002).

${ }^{62}$ Scott Morgenstern, "Organized Factions and Disorganized Parties: Electoral Incentives in Uruguay,” Party Politics 7 (March 2001).
} 
fail, however, then by definition the result is a minority government. Strom's work, by contrast, focuses on the incentives facing parties and posits that there may sometimes be a trade-off between enjoying current portfolios and enjoying future electoral success.

How do these considerations bear on the Brazilian case? There is not much change in the effective number of parliamentary parties from before Cardoso (7.9) to after (7.2). We have examined the cohesion of the big seven parties over time and do not find much change there, either (from before to after Cardoso). ${ }^{63}$ Neither the nature of Brazil's bicameralism nor the nature of its legislative committees has changed during the period under study. Finally, it is not clear that the Stromian trade-off parties face between accepting office now and winning votes later has cut very differently in the various administrations under consideration.

This leaves one factor that has changed. Brazil changed from a nonconcurrent to a concurrent electoral cycle in 1994, at Cardoso's first election. Thus, one might conjecture that Cardoso chose to build a large electoral coalition for both presidential and legislative purposes, then leveraged this into a workable legislative majority. Samuels's work documenting the importance of gubernatorial politics in structuring the elections of federal deputies suggests some definite limits to this line of thinking. ${ }^{64}$ Nonetheless, Samuels reports that presidential coattails, although not as large as gubernatorial, are statistically significant. They might thus provide some glue with which to put together a more stable legislative coalition, more or less along the standard lines of argument.

If aligning the executive and legislative electoral calendars in 1994 helps explain why Cardoso is the only recent Brazilian president to form a majority government, then one would expect his successors to follow suit. At this point, however, it is too early to tell.

\section{CONCLUSION}

In this article we have examined what we call parliamentary agenda cartels. A governing coalition of parties (that is, those holding cabinet portfolios) constitutes a parliamentary agenda cartel when they (1) take a controlling share of agenda-setting offices for themselves; and (2) de-

\footnotetext{
${ }^{63}$ Comparing average Rice indices of cohesion for 1991-95 and 1995-99, one finds two parties decreasing their cohesion: the PMDB (13 percentage points) and the PPB (5 points). Two parties exhibited small increases: the PT ( 3 points) and PDT (5 points). Three parties exhibited somewhat larger increases: the PSDB, PTB and PFL (all 12-14 points). Considering the size of the respective parties, there is not much net change in the cohesiveness of the parties with which a president would have to deal in forming a cartel.

${ }^{64}$ David Samuels, "Concurrent Elections, Discordant Results: Presidentialism, Federalism, and Governance in Brazil," Comparative Politics 33 (January 2000).
} 
cide the legislative agenda in a fashion that amounts to allowing each partner in the coalition to veto the placement of bills on the plenary agenda. This definition is abstract enough to apply both to traditional parliamentary regimes and to some presidential regimes (those in which the leaders of legislative parties can accept cabinet portfolios and either continue to sit in the assembly or retain the right to resume their assembly seats when they resign their portfolio). We are interested in how prevalent such parliamentary agenda cartels are in the world's legislatures. In particular, we focus on the cartel thesis: the proposition that if a majority government forms, then it will constitute a parliamentary agenda cartel.

Operationally, what are "majority governments" and how does one identify "parliamentary agenda cartels"? We define a government as the set of all legislative parties that hold cabinet portfolios. A majority government then is one whose component parties' seat shares-discounted by the quality of their representation in the cabinet - add up to a majority.

To identify parliamentary agenda cartels, we look for three observable patterns. First, the component parties of the putative cartel should each have roll rates that are comparable to those found for governing parties in parliamentary regimes (below 5 percent). Relatedly, there should be no systematic relationship between parties' ideological locations within the government and their roll rates. Second, the component parties of the cartel should each have a share of portfolios comparable to their share of seats within the government, as is the case in parliamentary regimes. Third, the chief executive-having lined up his legislative ducks - should actually use them to pass statutes and constitutional amendments, rather than relying primarily on decrees.

With definitions of majority government and agenda cartel in hand, we examined the case of Brazil's Chamber of Deputies. We found that only Cardoso's second cabinet was a majority government in the period we study (1989-98), with all other presidential cabinets being minority governments. We also found that only Cardoso formed an agenda cartel, with all three criteria for identifying such cartels telling a consistent story.

If Brazilian presidents always chose to form cartels, then our positions would be similar to that of Figueiredo and Limongi. These authors contend that all Brazilian presidents since 1988 have colluded with party leaders to use their agenda and patronage powers to buy the support of blocs of deputies. In their words: "Presidents 'form a government' in the same way as prime ministers do in multiparty systems." ${ }^{5}$

\footnotetext{
${ }^{65}$ Figueiredo and Limongi (fn. 3, 1999), 101.
} 
We agree that all presidents have formed support coalitions. However, the nature of the support coalitions for Brazilian presidents and European prime ministers differs substantially as regards the cabinet and legislative agenda. Prime ministers must constantly maintain majority support in the parliament. ${ }^{66}$ To this end, they typically appoint a cabinet of legislative party leaders; and they negotiate a legislative agenda with their partners that will be acceptable to all (lest a disgruntled partner defect on a vote of confidence and bring down the coalition). Brazilian presidents, by contrast, have more options. Their continuance in office does not require constantly maintaining a majority in the legislature. Thus, some presidents—-such as Sarney, Collor, and Franco-have chosen to rule more by decree, to appoint more technocratic or crony-based cabinets, and not to negotiate their legislative agenda with a stable majority support coalition. Unlike a typical majority parliamentary government, legislative supporters of these presidents had no guaranteed voice in setting the agenda. By contrast, some presidents-only Cardoso thus far, according to our figureshave chosen to rule more through statutes, to appoint more partisan cabinets, and to agree on a legislative agenda that all pivotal members of a stable support coalition - or agenda cartel — can live with. Given our findings on how the various parties have voted on agenda-setting votes, we would view only Cardoso as operating in a parliamentary style.

We believe that Brazil's legislative politics are neither consistently "atomistic" (per Ames) nor consistently "parliamentary" (per Figueiredo and Limongi). Instead, the pattern of governance in Brazil depends on an initial strategic choice made by the president, in light of the lay of the political land (per Altman, Amorim Neto, and Cox and Morgenstern). ${ }^{67}$ In the future more work needs to be done about the determinants of this initial presidential choice. In the present work we have shown that this choice does carry with it important consequences for the nature of the legislative process.

\footnotetext{
${ }^{66}$ Even minority governments must maintain a majority who tolerate their existence.

${ }^{67}$ David Altman, "The Politics of Coalition Formation and Survival in Multiparty Presidential Regimes" (Ph.D. diss., University of Notre Dame, 2001); Octavio Amorim Neto, "Of Presidents, Parties, and Ministers: Cabinet Formation and Legislative Decision-Making under Separation of Powers" (Ph.D. diss., University of California, San Diego, 1998); Gary W. Cox and Scott Mogenstern, "Latin America's Reactive Assemblies and Proactive Presidents," Comparative Politics 33 (March 2001).
} 


\section{E R R A T A}

The following are corrected Tables 1 (p. 563) and 3 (p. 569) for Neto, Cox, and McCubbins, "Agenda Power in Brazil's Câmara dos Deputados, 1989-98," which appeared in the July 2003 issue of World Politics. The corrections are indicated in boldface.

TABLE 1

Roll Rates on Project and Agenda-Setting Votes, per Cabinet(s) AND PARTy in BRazil's Chamber of DePuties

(1989-98)

\begin{tabular}{|c|c|c|c|c|c|c|c|c|}
\hline \multirow[b]{2}{*}{ Presidential Cabinet $(s)^{a}$} & \multirow{2}{*}{$\begin{array}{c}\text { Number } \\
\text { of } \\
\text { Roll Calls }\end{array}$} & \multicolumn{7}{|c|}{ Parties $^{\mathrm{b}}$} \\
\hline & & $P T$ & $P D T$ & $P S D B$ & $P M D B$ & PTB & $P F L$ & $P P B$ \\
\hline Sarney 3 (1/89-3/90) & 18 & 88.9 & 77.8 & 38.9 & $\underline{0}$ & 16.7 & $\underline{5.6}$ & 11.1 \\
\hline Collor $1(3 / 90-10 / 90)$ & 9 & 100 & 100 & 33.3 & 22.2 & 0 & $\underline{0}$ & 0 \\
\hline Collor 2 (10/90)-1/91) & 2 & 100 & 100 & 50 & 0 & 0 & $\underline{0}$ & 0 \\
\hline Collor 3 + 4 (2/91-10/92) & 38 & 73.7 & 52.6 & 36.8 & 5.3 & 10.5 & $\underline{15.8}$ & 23.7 \\
\hline Franco 1-5 (10/92-12/94) & 25 & 72.0 & 52.0 & $\underline{8.0}$ & $\underline{4.0}$ & 16.0 & $\underline{16.0}$ & 20.0 \\
\hline Cardoso $1+2(1 / 95-12 / 98)$ & ) 161 & 88.2 & 79.5 & 1.8 & $\underline{3.1}$ & $\underline{4.3}$ & $\underline{1.8}$ & 6.2 \\
\hline
\end{tabular}

${ }^{a}$ Collor was removed from office on corruption charges in October 1992, having been replaced by his vice mate Franco. The president's term was reduced from five to four years in 1994. That is why Sarney served for five years, while Cardoso served for four in his first term. Cardoso was elected for a second four-year term in October 1998.

${ }^{\mathrm{b}}$ Underlining indicates that a party was in the president's nominal support coalition.

TABLE 3

Executive-Initiated Statutory Bills, Bills of Complementary Laws, Constitutional Amendments, and Decree-Laws Per Presidential Cabinet(s)

\begin{tabular}{|c|c|c|c|c|c|}
\hline $\begin{array}{l}\text { Presidential } \\
\text { Cabinet(s) } \\
\end{array}$ & $\begin{array}{c}\text { Statutory } \\
\text { Bills } \\
(S B)\end{array}$ & $\begin{array}{l}\text { Bills of } \\
\text { Comple- } \\
\text { mentary } \\
\text { Laws } \\
\text { (CL) }\end{array}$ & $\begin{array}{c}\text { Constitu- } \\
\text { tional } \\
\text { Amendments } \\
\text { (CA) }\end{array}$ & $\begin{array}{c}\text { Decree- } \\
\text { Laws } \\
(D L)\end{array}$ & $\begin{array}{c}\text { Index of } \\
\text { Standard Legislative } \\
\text { Initiatives } \\
S L I=(S B+C L+C A) / \\
(S B+C L+C A+D L)\end{array}$ \\
\hline $\begin{array}{l}\text { Sarney } 3 \\
\qquad(1 / 89-3 / 90)\end{array}$ & 142 & 15 & 0 & 109 & 0.59 \\
\hline $\begin{array}{l}\text { Collor } 1 \\
\qquad(3 / 90-10 / 90)\end{array}$ & 37 & 1 & 0 & 56 & 0.40 \\
\hline $\begin{array}{l}\text { Collor } 2 \\
\quad(10 / 90)-1 / 91)\end{array}$ & 43 & 3 & 0 & 18 & 0.72 \\
\hline $\begin{array}{l}\text { Collor } 3+4 \\
\quad(2 / 91-10 / 92)\end{array}$ & 259 & 19 & 2 & 11 & 0.96 \\
\hline $\begin{array}{l}\text { Franco } 1-5 \\
\qquad(10 / 92-12 / 94)\end{array}$ & 262 & 25 & 3 & 152 & 0.66 \\
\hline $\begin{array}{l}\text { Cardoso } 1+2 \\
\quad(1 / 95-12 / 98)\end{array}$ & 484 & 48 & 30 & 158 & 0.78 \\
\hline
\end{tabular}

SourcE: Brazil-Senado Federal (1999) (www.senado.gov.br); data provided by Argelina C. Figueiredo and Fernando Limongi. 